\title{
Contrasting Effects of Central Pacific and Eastern Pacific EI Niño on stratospheric water vapor
}

\author{
Chaim I. Garfinkel, ${ }^{1,2}$ Margaret M. Hurwitz, ${ }^{3,4}$ Luke D. Oman, ${ }^{4}$ and Darryn W. Waugh ${ }^{1}$ \\ Received 7 May 2013; revised 14 June 2013; accepted 17 June 2013; published 8 August 2013.
}

[1] Targeted experiments with a comprehensive chemistryclimate model are used to demonstrate that seasonality and the location of the peak warming of sea surface temperatures dictate the response of stratospheric water vapor to El Niño. In boreal spring, El Niño events in which sea surface temperature anomalies peak in the eastern Pacific lead to a warming at the tropopause above the warm pool region, and subsequently to more stratospheric water vapor (consistent with previous work). However, in fall and in early winter, and also during El Niño events in which the sea surface temperature anomaly is found mainly in the central Pacific, the response is qualitatively different: temperature changes in the warm pool region and specifically over the cold point region are nonuniform, and less water vapor enters the stratosphere. The difference in water vapor in the lower stratosphere between the two variants of El Niño approaches 0.3 ppmv, while the difference between the winter and spring responses exceeds 0.5 ppmv. Citation: Garfinkel, C. I., M. M. Hurwitz, L. D. Oman, and D. W. Waugh (2013), Contrasting effects of Central Pacific and Eastern Pacific El Niño on stratospheric water vapor, Geophys. Res. Lett., 40, 4115-4120, doi:10.1002/grl.50677.

\section{Introduction}

[2] A comprehensive understanding of interannual variability in the amount of water vapor entering the stratosphere remains elusive. In the time-mean boreal wintertime, enhanced convection and diabatic heating over the IndoPacific warm pool (hereafter warm pool) region leads to lower temperatures near the tropopause in this region [Highwood and Hoskins, 1998; Fueglistaler et al., 2009]. These low temperatures govern the amount of water vapor that can reach higher in the stratosphere [Mote et al., 1996; Fueglistaler et al., 2004; Fueglistaler and Haynes, 2005; Oman et al., 2008]. Temperatures near the coldest region at the tropopause (hereafter CPR, for cold point region) change on interannual timescales, however. As the amount of water vapor that enters the stratosphere is important for stratospheric chemistry [Solomon

\footnotetext{
Additional supporting information may be found in the online version of this article.

${ }^{1}$ Department of Earth and Planetary Science, Johns Hopkins University, Baltimore, Maryland, USA.

${ }^{2}$ Now at Institute of Earth Science, Hebrew University, Jerusalem, Israel.

${ }^{3}$ NASA GESTAR, Morgan State University, Greenbelt, Maryland, USA.

${ }^{4}$ NASA GSFC, Greenbelt, Maryland, USA.

Corresponding author: C. I. Garfinkel, Department of Earth and Planetary Science, Johns Hopkins University, Baltimore, MD 21218, USA. (cig4@jhu.edu)

(C)2013. American Geophysical Union. All Rights Reserved. 0094-8276/13/10.1002/grl.50677
}

et al., 1986] and radiative balance [Forster and Shine, 1999; Solomon et al., 2010], it is important to understand the factors that control its entry into the stratosphere on all timescales.

[3] The El Niño-Southern Oscillation (ENSO) is the dominant mode of interannual variability in the Tropics, and it has been connected to variability of the CPR [Kiladis et al., 2001; Scaife et al., 2003; Calvo Fernández et al., 2004; Garcia et al., 2007; Xie et al., 2012; Scherllin-Pirscher et al., 2012, among others]. While these studies differ in the data used and the time period chosen, they conclude that El Niño (EN) leads to a Rossby wave response whereby anomalously warm temperatures are present over the warm pool region. This subsequently leads to more water vapor entering the stratosphere [Zhou et al., 2004; Fueglistaler and Haynes, 2005; Liang et al., 2011].

[4] However, no two EN events are identical, and these different variants (or "flavors") of EN may lead to different atmospheric teleconnections in the tropical tropopause layer, hereafter TTL. During "traditional" EN events, warm sea surface temperature anomalies (SSTa) are present in the equatorial East Pacific. This variant of EN will be referred to as East Pacific warming, or EPW, in the rest of this manuscript. During many recent El Niño events, however, warm SSTa were concentrated in the central Pacific (CPW, or central Pacific warming) [Trenberth and Stepaniak, 2001; Larkin and Harrison, 2005; Yu and Kao, 2007; Ashok et al., 2007; Kug et al., 2009; Kao and Yu, 2009]. It is important to understand how these two forms of EN affect CPR temperatures and stratospheric water vapor. Xie et al. [2012] considered this issue but focused on the tropopause level and below.

[5] This paper will use modeling experiments to demonstrate that the moistening of the stratosphere due to EN occurs mainly in the late boreal spring while the EN event is decaying, even though the strongest impact on tropopause temperatures is several months earlier. In addition, they demonstrate that while the two variants of EN have generally similar imprints on the tropical tropopause temperatures near the warm pool, the subtle differences between them lead to qualitatively different impacts on stratospheric water vapor.

\section{Methods and Models}

[6] Modeling experiments with the Goddard Earth Observing System Chemistry-Climate Model, Version 2 (GEOSCCM) (Rienecker et al. [2008] and section 2.2 of Hurwitz et al. [2010]) are used to isolate the impact of $\mathrm{CPW}$ and EPW on tropopause temperature and water vapor. The GEOSCCM couples the GEOS-5 atmospheric global climate model (GCM) [Rienecker et al., 2008] with a comprehensive stratospheric chemistry module [Pawson et al., 
2008]. The model has 72 vertical layers, with a model top at $0.01 \mathrm{hPa}$, and all simulations discussed here were performed at $2^{\circ}$ latitude $\times 2.5^{\circ}$ longitude horizontal resolution. The convection scheme used in GEOSCCM is based on Relaxed Arakawa-Schubert [Moorthi and Suarez, 1992; Rienecker et al., 2008; Molod et al., 2012]. The model vertical levels between $150 \mathrm{hPa}$ and $50 \mathrm{hPa}$ are located at $139.1 \mathrm{hPa}$, $118.3 \mathrm{hPa}, 100.5 \mathrm{hPa}, 85.4 \mathrm{hPa}, 72.6 \mathrm{hPa}, 61.5 \mathrm{hPa}$, and $52.0 \mathrm{hPa}$; output is plotted at standard pressure levels. The tropopause height is defined using a blended approach which takes the lower of a potential vorticity-based tropopause and a thermally based tropopause.

[7] On plots of $100 \mathrm{hPa}$ temperature, the CPR during EN is enclosed with a green contour; it bounds the coldest $10 \%$ of the Tropics between $30^{\circ} \mathrm{S}$ and $30^{\circ} \mathrm{N}$. The climatological CPR is enclosed by a cyan line; it encloses the coldest $10 \%$ of the tropics from $30^{\circ} \mathrm{S}$ to $30^{\circ} \mathrm{N}$ for each season and corresponds to $189.70 \mathrm{~K}$ for November-December-JanuaryFebruary (NDJF) and 190.78 K for April-May-June (AMJ). The $10 \%$ threshold is chosen to match the approximate size of the CPR as shown by Fueglistaler et al. [2004] and in Figures 1 and 4 of Oman et al. [2008]. However, this is just an approximate measure of coldest temperatures at tropical tropopause, and results are not sensitive to choosing, e.g., the $6 \%$ or $14 \%$ threshold. Temperature anomalies at $85 \mathrm{hPa}$ resemble quantitatively those at $100 \mathrm{hPa}$, and we therefore show $100 \mathrm{hPa}$ anomalies only for brevity. Stratospheric Processes and their Role in ClimateChemistry-Climate Validation Activity (SPARC-CCMVal) [2010] and Gettelman et al. [2010] grade highly the representation of stratospheric water vapor and lower stratospheric temperatures by an earlier version of GEOSCCM as compared to observations and to the multimodel mean of an ensemble of CCMs.

[8] In order to isolate the impact of changing SSTs, other external boundary conditions are held fixed. Greenhouse gas and ozone-depleting substance concentrations are specified in the boundary layer to represent the year 2005 in all experiments discussed here. (Within the atmosphere, their concentrations depend on transport and chemistry and subsequently feed back to the radiative calculations.) In addition, variability related to the solar cycle and volcanic aerosols are not considered.

[9] The first group of model integrations are those used in Hurwitz et al. [2011] and Garfinkel et al. [2012] to isolate the impact of CPW and EPW on the Pacific-North America region and the boreal winter stratosphere. Briefly, Garfinkel et al. [2012] examined four 50 year time-slice simulations forced by repeating annual cycles of sea surface temperatures and sea ice that represent CPW, EPW, and La Niña (in which negative SSTa are present in the eastern and central equatorial Pacific; hereafter LN) events. The SSTa used to force the simulations are shown in Figure 2 of Garfinkel et al. [2012] and are repeated here in Figure 1. The CPW SSTa peaks in the Central Pacific while the EPW SSTa peaks in the Eastern Pacific. We have also examined the response in the CPW ideal experiment from Garfinkel et al. [2012] (in which the SST anomalies are identically zero outside of the tropical Central Pacific), and the anomalies are quantitatively similar to those in the CPW experiment (e.g., the pattern correlation with the water vapor anomalies shown in Figure 1d is 0.97). The key point is that these model integrations provide many samples of the atmospheric response to identical
SSTa and are long enough to achieve statistical robustness (as discussed in Garfinkel et al. [2012, section 5]). Statistical significance is determined by a two-tailed Student's $t$ test.

[10] The second group of model integrations is a sixmember ensemble of GEOSCCM in which all sources of externally forced variability are removed except for one: the sea surface temperatures. The SSTs follow those observed in the years 1980 to 2006 [Rayner et al., 2003]. Each of the six differ slightly in their physical parameterizations, whereby two of the ensemble members include an internally generated quasi-biennial oscillation and four do not. All results shown here are robust to excluding those ensemble members with a quasi-biennial oscillation. The key point is that these simulations isolate the impact of SST variations from 1980 to 2006 on the TTL. A composite of eastern Pacific warming events is formed of winters in which the anomalous SSTs in the Nino3 region $\left(150^{\circ} \mathrm{W}\right.$ to $90^{\circ} \mathrm{W}$, $5^{\circ} \mathrm{S}$ to $5^{\circ} \mathrm{N}$ ) exceeds its climatological value by $0.85 \mathrm{~K}$. Results are similar if a threshold of $0.7 \mathrm{~K}$ or $1 \mathrm{~K}$ is used. The EPW winters included are: 82/83, 87/88, 91/92, 97/98, and $02 / 03$. A similar composite of Central Pacific warming events is formed of winters in which the index $1.5^{*} \mathrm{Nino}$ $4-0.5 *$ Nino 3 exceeds its climatological value by $0.5 \mathrm{~K}$ and which are not already characterized as EPW events (the Nino4 region is $160^{\circ} \mathrm{E}$ to $150^{\circ} \mathrm{W}, 5^{\circ} \mathrm{S}$ to $\left.5^{\circ} \mathrm{N}\right)$. The $\mathrm{CPW}$ winters included are: 90/91, 94/95, and 04/05. Results are qualitatively similar if a threshold of $0.35 \mathrm{~K}$ is used, or if we use one of the other CPW definitions considered in Garfinkel et al. [2012] (unlike the polar stratospheric response, which is highly sensitive to CPW definition). Results are also not sensitive to forming composites based on tropical precipitation anomalies, as opposed to SST anomalies (see supporting information). The La Niña years used are 84/85, 88/89, $98 / 99,99 / 00$, and $05 / 06$; we find little sensitivity in the LN years composited when we use either the CP or the EP definition. The impact of SST trends on near-tropopause trends in these integrations is considered in (C. I. Garfinkel et al., Upper tropospheric and lower stratospheric zonally asymmetric tropical temperature trends forced by sea surface temperature trends: Implications for water vapor and ozone, submitted to J. Geophys. Res, 2013). Nonlinearity between the EN and LN responses is discussed in the supporting information. Statistical robustness is determined by evaluating the fraction of the ensemble members who agree on the sign of the anomaly. Light red or blue is added when five out of six of the ensemble members agree on the sign of the change, and dark red or blue is added when all six ensemble members agree on the sign of the anomaly.

[11] Combined, the two groups of models allow a more comprehensive assessment of the impact of ENSO on the tropopause region and the lower stratosphere. The sixmember ensemble simulates the complete life cycle of specific, observed ENSO events. The 50 year perpetual ENSO integrations can isolate the response to a given SST distribution with more confidence than in the six-member ensemble.

\section{Results}

[12] We begin with the tropical water vapor response in the 50 year perpetual ENSO integrations. The seasonal evolution of water vapor for the EPW experiment is shown in Figure 1c, and the seasonal evolution for the $\mathrm{CPW}$ 
SST in the perpetual ENSO experiments
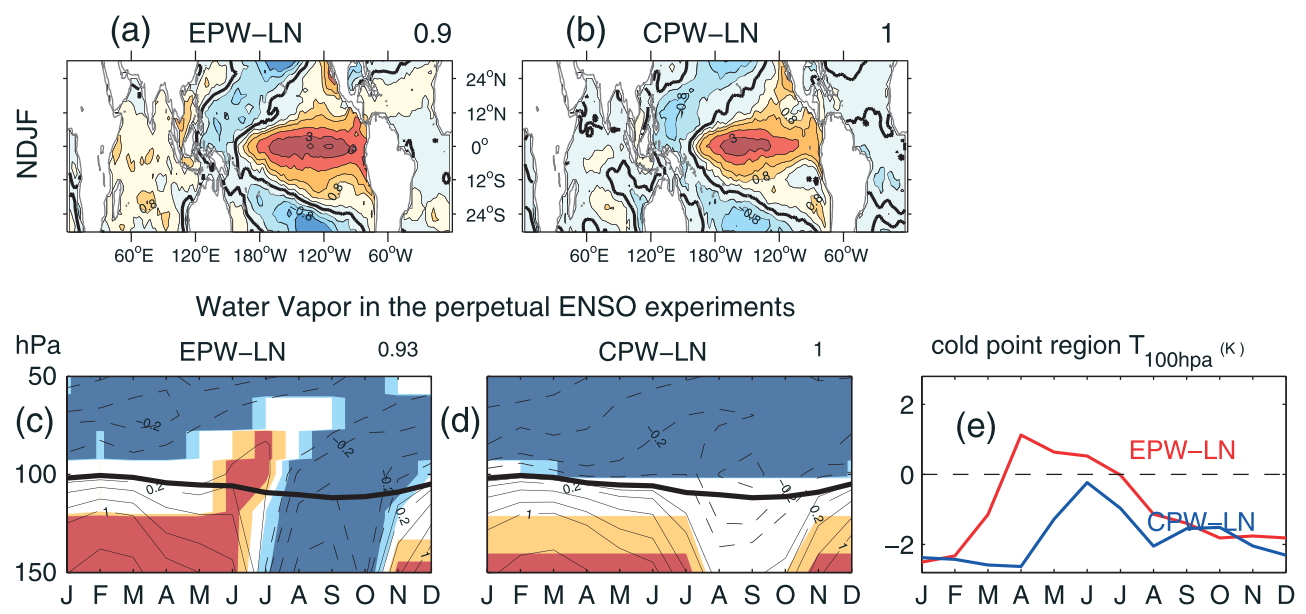

Figure 1. Sea surface temperature, tropical water vapor $\left(20^{\circ} \mathrm{S}-20^{\circ} \mathrm{N}\right)$, and cold point temperature anomalies in the perpetual CPW and EPW GEOSCCM integrations. (a, b) Contours are shown at $\pm 0.4, \pm 0.8, \pm 1.2, \pm 2$, and \pm 3 ; region with large warming (cooling) are colored red (blue). (c-d) Contours are shown at $\pm 0.1, \pm 0.2, \pm 0.4, \pm 0.7, \pm 1$ ppmv, and regions with anomalies significant at the $90 \%$ (99\%) level are colored orange (red) or light blue (dark blue). A solid black contour indicates the climatological position of the tropopause. The pattern correlation between the CPW and EPW anomalies are shown in the title of Figure 1a-1d. (e) The temperature anomaly associated with EN averaged in the cold point regions at $100 \mathrm{hPa}$ (as defined in section 2) for each calendar month.

experiment is shown in Figure 1d. Tropospheric water vapor is increased during the mature phase (November-February) of all variants of EN. However, the stratospheric water vapor concentrations depend crucially on the variant of EN. Namely, the stratosphere is drier during CPW than during EPW. In the annual average, the water vapor anomaly at $70 \mathrm{hPa}$ in the EPW experiment is -0.13 ppmv; in the CPW experiment, it is -0.33 ppmv. The difference in response between the CPW experiment and both the LN experiment and the EPW experiment is statistically significant at the 99\% level. The difference between EPW and CPW peaks at 0.3 ppmv for certain calendar months. Furthermore, pronounced seasonality is evident in the water vapor response. For both the EPW and CPW experiments, moister air parcels enter the stratosphere during spring (April-June) than during other calendar months. Even though ENSO events typically peak in early winter, the moistening of the lower stratosphere noted by previous work [e.g., Zhou et al., 2004; Fueglistaler and Haynes, 2005; Liang et al., 2011] is delayed until late spring. In the rest of this paper, we will address two question: (1) Why is the plume of increased water vapor that is apparently caused by both EN variants delayed until spring? and (2) Why is there more stratospheric water vapor during EPW than during CPW?

[13] In the interest of brevity, we will answer these questions by focusing on the response in the six-member ensemble as the seasonality of the response (and in particular of the decaying phase of EN) is more realistic in these experiments. However, all of the features described apply to the perpetual ENSO experiments as well.

[14] Figure 2 shows composites of SSTa, tropopause temperature, and water vapor, during EPW (top half) and CPW (bottom half). In all seasons and for both types of EN, the tropopause temperature response resembles a Rossby wave over the Indian Ocean and Western Pacific, and a meridional dipole straddling the equator over the central and eastern Pacific [as in Xie et al., 2012]. However, subtle differences exist among the different calendar months and between CPW and EPW, and these differences influence the response of water vapor to EN.

[15] We start with a discussion of the seasonality of the response during EPW. In NDJF, two factors lead to net cooling of the CPR at $100 \mathrm{hPa}$. First, the warming at $100 \mathrm{hPa}$ over the warm pool region does not extend as far into the Central Pacific as compared to AMJ (Figures 2b and 2d). Therefore, only part of the origination region for stratospheric water vapor (i.e., the area enclosed by the green isotherm) warms. Second, the CPR is shifted eastward due to the warming associated with EPW. EPW induces a net warming of the climatological CPR (i.e., the area enclosed by a cyan contour), but not of the CPR after it has been shifted (i.e., the area enclosed by a green contour). This is shown by the dashed red (fixed CPR) and solid red (EN CPR) lines in Figure 2i. Finally, the CPR cools in NDJF: the temperature of the coldest $10 \%$ of the Tropics (i.e., the area enclosed by the cyan and green contours) cools by $0.25 \mathrm{~K}$.

[16] In contrast, in AMJ, the CPR warms at $100 \mathrm{hPa}$ (Figure 2i). First, the warming over the warm pool region extends further toward the central Pacific. In addition, during AMJ, the origination region for stratospheric water vapor begins to extend toward the Indian subcontinent (cf. green isotherm in Figure 2d), and in this region, EPW induces warming at $100 \mathrm{hPa}$. Finally, the CPR warms in AMJ: the temperature of the coldest $10 \%$ of the Tropics (i.e., the temperature marked by a green contour) increases by $0.35 \mathrm{~K}$ during EPW as compared to climatology. In summary, EPW causes the CPR to cool in fall and winter, but to warm in spring. Hence, we see a transition from a dryer lower stratosphere in NDJF to a moister lower stratosphere in springtime.

[17] During CPW, the temperature response at $100 \mathrm{hPa}$ is generally similar to that of EPW. However, subtle differences exist between the CPW and EPW responses, and these differences lead to a dryer springtime stratosphere during 

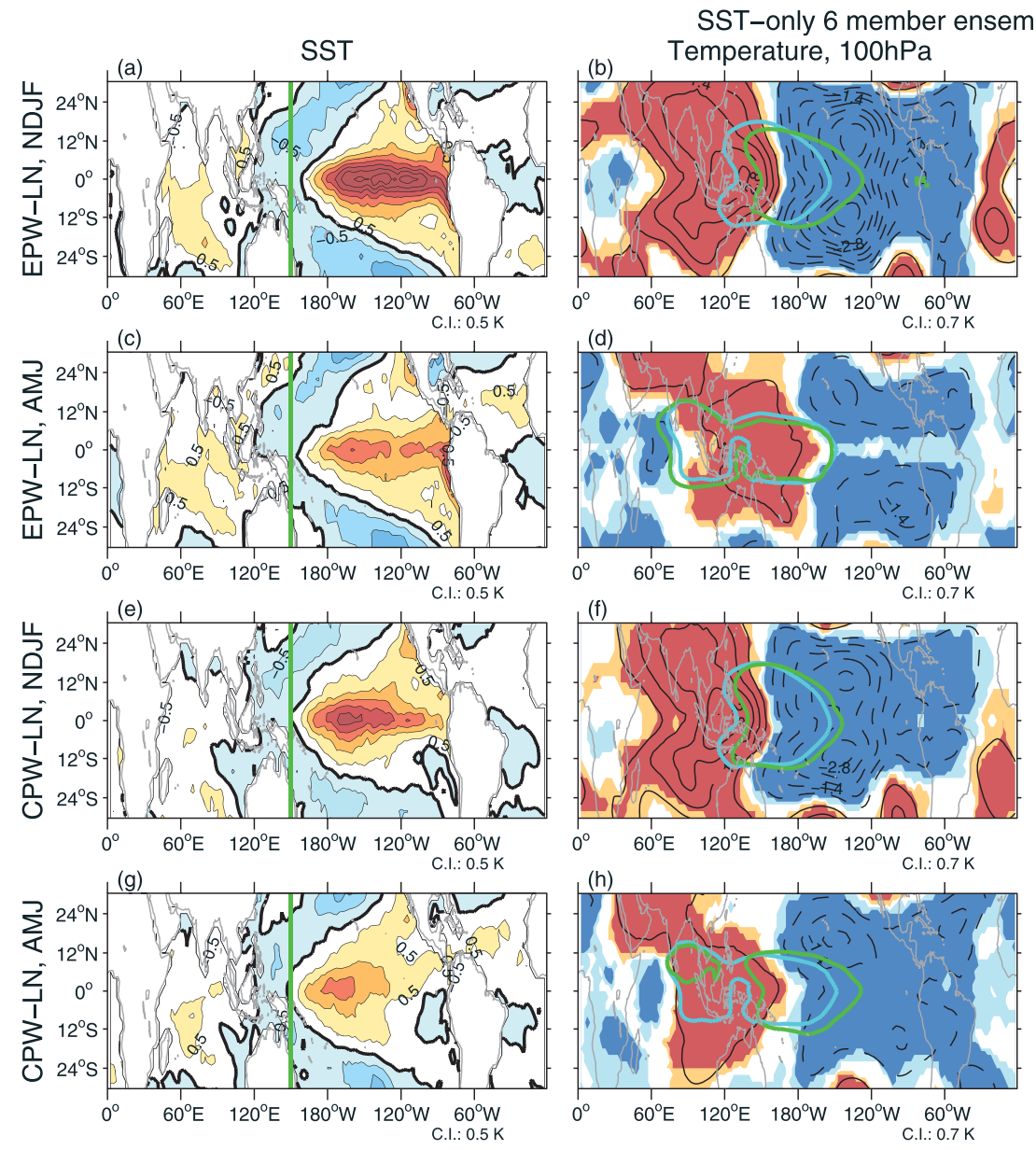

Figure 2. Response to EPW and CPW in the ensemble mean of the six-member ensemble forced with observed SSTs only. (a-d) EPW and (e-h) CPW. (Figures 2a, 2b, 2e, and 2f) NDJF and (Figures 2c, 2d, 2g, and 2h) AMJ. (left column) Sea surface temperature; (middle column) temperature at $100 \mathrm{hPa}$; (right column) cold point temperature (as in Figure 1e) and zonally averaged water vapor, with contours shown at $\pm 0.1 \mathrm{ppmv}, \pm 0.2 \mathrm{ppmv}, \pm 0.4 \mathrm{ppmv}, \pm 0.6 \mathrm{ppmv}, \pm 0.8 \mathrm{ppmv}$, and \pm 1.5 ppmv. For the middle and right columns, color indicates regions in which the model responses are robust among the ensemble members. A dashed red line on Figure 2i shows the average temperature in the region included climatologically in the cold point region (the cyan contour; fixed cold point). Figure $2 \mathrm{i}$ includes the average cold point temperature if a threshold of $6 \%$ or $14 \%$ is used instead of $10 \%$ with a thin line. A solid black contour indicates the climatological position of the tropopause in Figures $2 \mathrm{j}-2 \mathrm{k}$.

CPW as compared to EPW. First, the magnitude of the temperature anomalies in the TTL is approximately $50 \%$ larger during EPW than during CPW in all seasons. The weakening of CPW teleconnections relative to EPW teleconnections is consistent with the underlying SSTa: the magnitude of the SSTa is approximately $50 \%$ weaker during CPW than during EPW. In addition, the warm anomaly over the warm pool region during CPW does not extend as far east into the Pacific (this can be seen by comparing the location of the node near $180^{\circ}$ in Figure 2d versus Figure 2h). The zonal extent of the warm anomaly at $100 \mathrm{hPa}$ is related to the underlying SST anomalies in each ENSO type, as the positive SSTa in the tropical Pacific Ocean during CPW extend further to the west than those of EPW (Figures 2c and 2g). The upper tropospheric tropical temperature response is also westward shifted during CPW as compared to EPW (not shown). The net effect is that in AMJ, the CPR warms, and the lower stratosphere moistens more during EPW than during CPW (cf. Figures $2 \mathrm{i}$ and 2k).
[18] In summary, the net warming of the CPR associated with EN peaks in the late spring after the EN event has already substantially decayed (Figures 1e and 2i). Hence, the plume of enhanced stratospheric water vapor is delayed until the late spring following an EN event. The warming of the $\mathrm{CPR}$ is stronger and more pervasive during EPW than during CPW (Figures 1e and 2i). Therefore, the lower stratosphere is moister during EPW events.

\section{Conclusions}

[19] Targeted chemistry-climate model experiments are used to demonstrate the importance of seasonality and the variant of El Niño event when evaluating the response of water vapor to El Niño. There are two main conclusions to this study:

[20] 1. El Niño events in which sea surface temperature anomalies peak in the eastern Pacific lead to significantly more water vapor entering the stratosphere as compared 
correlation between $85 \mathrm{hPa}$ water vapor and tropical SSTs

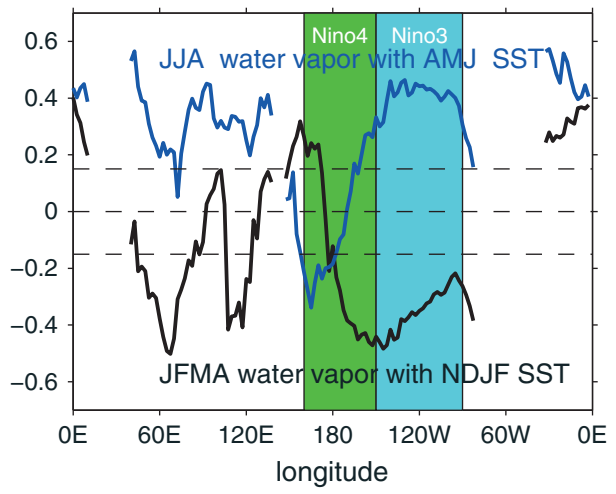

Figure 3. The correlation between equatorial $\left(5^{\circ} \mathrm{S}-5^{\circ} \mathrm{N}\right)$ SST anomalies and zonal-mean water vapor anomalies at 85 hPA 2 months later. November through February (NDJF) SST with January through April (JFMA) water vapor (red), and April through June (AMJ) SST with June through August (JJA) water vapor (blue). The Nino3 and Nino4 regions are indicated directly on the figure with cyan and green. Correlations whose absolute value exceeds 0.15 are statistically significant at the $95 \%$ level by a two-tailed Student's $t$ test; these values are indicated on the figure.

to El Niño events in which the sea surface temperature anomaly is found mainly in the central Pacific. The difference approaches $0.3 \mathrm{ppmv}$ in certain calendar months.

[21] 2. The moistening of the lower stratosphere in response to El Niño occurs mainly in spring. In contrast, in winter, El Niño leads to a drying of the lower stratosphere. The difference between the winter and spring responses exceeds 0.5 ppmv.

[22] Both of these features are consistent with, and are driven by, the temperature anomalies in the Indo-Pacific region, and in particular near the cold point, at $100 \mathrm{hPa}$.

[23] The connection between SSTa and stratospheric water vapor anomalies is summarized by Figure 3, which shows the correlation between stratospheric water vapor and tropical SSTa at a lead of 2 months. A 2 month lead is chosen as it approximates the timescale for water vapor anomalies to reach the $85 \mathrm{hPa}$ level (cf. Figures $1 \mathrm{c}, 1 \mathrm{~d}, 2 \mathrm{j}$, and $2 \mathrm{k}$ ). Correlation coefficients exceeding 0.6 are present in the tropical Pacific Ocean. During NDJF, La Niña SSTa lead to moistening of the stratosphere 2 months later, while during AMJ, warming in the eastern Pacific (but not in the central Pacific) leads to moistening of the stratosphere 2 months later. For reference, the Nino3 and Nino4 regions are indicated directly on the figure; these two regions are imperfect if one wishes to isolate the SST pattern that most strongly leads to moistening of the stratosphere. In addition, Figure 3 emphasizes the importance of seasonality when considering the response of stratospheric water vapor to ENSO.

[24] Unfortunately, the available satellite data on stratospheric water vapor is too short to discriminate a statistically significant difference between the El Niño variants in observations. In addition, the complexity of the sequence of physical events leading from SST forcing to stratospheric response raises questions about any conclusions based on an individual atmospheric GCM. For future work, we plan on examining these effects in CCMVal (and Coupled Model
Intercomparison Project Phase 5) models. However, the model output presented here clearly shows that subtle temperature differences at $100 \mathrm{hPa}$ between winter and spring, and between different El Niño variants, can lead to dramatic differences in stratospheric water vapor. As many coupled ocean-atmosphere models have trouble reproducing the observed diversity of ENSO events in the present-day climate [Kim and Yu, 2012], they likely miss these subtle differences. If central Pacific El Niño events are becoming more frequent (as suggested by Yeh et al. [2009] though disputed by L'Heureux et al. [2012]), then the overall impact of ENSO on stratospheric water vapor will likely change.

[25] Acknowledgment. This work was supported by NSF grants AGS-1036858 and ATM-0905863.

[26] The Editor thanks two anonymous reviewers for their assistance in evaluating this paper.

\section{References}

Ashok, K., S. K. Behera, S. A. Rao, H. Weng, and T. Yamagata (2007), El Niño Modoki and its possible teleconnection, J. Geophys. Res., 112, C11007, doi:10.1029/2006JC003798.

Calvo Fernández, N., R. R. García, R. García Herrera, D. Gallego Puyol, L. Gimeno Presa, E. Hernández Martín, and P. Ribera Rodríguez (2004), Analysis of the ENSO signal in tropospheric and stratospheric temperatures observed by MSU, 1979 2000, J. Clim., 17, 3934-3946, doi:10.1175/1520-0442(2004)017h3934:AOTESIi2.0.CO;2.

Forster, P. M., and K. P. Shine (1999), Stratospheric water vapor changes as a possible contributor to observed stratospheric cooling, Geophys. Res. Lett., 26, 3309-3312, doi:10.1029/1999GL010487.

Fueglistaler, S., and P. H. Haynes (2005), Control of interannual and longerterm variability of stratospheric water vapor, J. Geophys. Res., 110, D24108, doi:10.1029/2005JD006019.

Fueglistaler, S., H. Wernli, and T. Peter (2004), Tropical troposphere-tostratosphere transport inferred from trajectory calculations, J. Geophys. Res., 109, D03108, doi:10.1029/2003JD004069.

Fueglistaler, S., A. E. Dessler, T. J. Dunkerton, I. Folkins, Q. Fu, and P. W. Mote (2009), Tropical tropopause layer, Rev. Geophys., 47, RG1004, doi:10.1029/2008RG000267.

Garcia, R. R., D. Marsh, D. Kinnison, B. Boville, and F. Sassi (2007), Simulations of secular trends in the middle atmosphere, 1950-2003, J Geophys. Res., 112, D09301, doi:10.1029/2006JD007485.

Garfinkel, C. I., M. M. Hurwitz, D. W. Waugh, and A. H. Butler (2012), Are the teleconnections of Central Pacific and Eastern Pacific El Niño distinct in boreal wintertime? Clim. Dyn., 1-18, doi:10.1007/s00382012-1570-2.

Gettelman, A., et al. (2010), Multimodel assessment of the upper troposphere and lower stratosphere: Tropics and global trends, J. Geophys. Res., 115, D00M08, doi:10.1029/2009JD013638.

Highwood, E. J., and B. J. Hoskins (1998), The tropical tropopause, Q. J. R. Meteorol. Soc., 124, 1579-1604, doi:10.1002/qj.49712454911.

Hurwitz, M. M., P. A. Newman, F. Li, L. D. Oman, O. Morgenstern, P. Braesicke, and J. A. Pyle (2010), Assessment of the breakup of the Antarctic polar vortex in two new chemistry-climate models, J. Geophys. Res., 115, D07105, doi:10.1029/2009JD012788.

Hurwitz, M. M., I.-S. Song, L. D. Oman, P. A. Newman, A. M. Molod, S. M. Frith, and J. E. Nielsen (2011), Response of the Antarctic stratosphere to warm pool El Niño events in the GEOS CCM, Atmos. Chem. Phys., 11, 9659-9669, doi:10.5194/acp-11-9659-2011.

Kao, H.-Y., and J.-Y. Yu (2009), Contrasting Eastern-Pacific and Central-Pacific types of ENSO, J. Clim., 22, 615-632, doi:10.1175 2008JCLI2309.1.

Kiladis, G. N., K. H. Straub, G. C. Reid, and K. S. Gage (2001), Aspects of interannual and intraseasonal variability of the tropopause and lower stratosphere, Q. J. R. Meteorol. Soc., 127, 1961-1983, doi:10.1002/qj.49712757606.

Kim, S. T., and J.-Y. Yu (2012), The two types of ENSO in CMIP5 models, Geophys. Res. Lett., 39, L11704, doi:10.1029/2012GL052006.

Kug, J.-S., F.-F. Jin, and S.-I. An (2009), Two types of El Niño events: Cold tongue El Niño and warm pool El Niño, J. Clim., 22, 1499-1515, doi:10.1175/2008JCLI2624.1.

Larkin, N. K., and D. E. Harrison (2005), Global seasonal temperature and precipitation anomalies during El Niño autumn and winter, Geophys. Res. Lett., 32, L16705, doi:10.1029/2005GL022860.

L'Heureux, M. L., D. C. Collins, and Z.-Z. Hu (2012), Linear trends in sea surface temperature of the tropical Pacific Ocean and 


\section{GARFINKEL ET AL.: ENSO AND WATER VAPOR}

implications for the El Niño-Southern Oscillation, Clim. Dyn., 40, $1223-$ 1236, doi:10.1007/s00382-012-1331-2.

Liang, C. K., A. Eldering, A. Gettelman, B. Tian, S. Wong, E. J. Fetzer, and K. N. Liou (2011), Record of tropical interannual variability of temperature and water vapor from a combined AIRS-MLS data set, $J$. Geophys. Res., 116, D06103, doi:10.1029/2010JD014841.

Molod, A., L. Takacs, M. Suarez, J. Bacmeister, I.-S. Song, and A. Eichmann, (2012), The GEOS-5 atmospheric general circulation model: Mean climate and development from MERRA to Fortuna, Tech. Rep. Ser. on Global Model. and Data Assim., 28, NASA Goddard Space and Flight Center, Greenbelt, MD. [Available at https://gmao.gsfc.nasa.gov/ pubs/docs/Molod484.pdf].

Moorthi, S., and M. J. Suarez (1992), Relaxed Arakawa-Schubert. A parameterization of moist convection for general circulation models, Mon. Weather Rev., 120, 978-1002, doi:10.1175/1520-0493(1992)120h0978: RASAPOi2.0.CO;2.

Mote, P. W., K. H. Rosenlof, M. E. McIntyre, E. S. Carr, J. C. Gille, J. R. Holton, J. S. Kinnersley, H. C. Pumphrey, J. M. Russell III, and J. W. Waters (1996), An atmospheric tape recorder: The imprint of tropical tropopause temperatures on stratospheric water vapor, J. Geophys. Res. 101, 3989-4006, doi:10.1029/95JD03422.

Oman, L., D. W. Waugh, S. Pawson, R. S. Stolarski, and J. E. Nielsen (2008), Understanding the changes of stratospheric water vapor in coupled chemistry-climate model simulations, J. Atmos. Sci., 65, 3278-3291, doi:10.1175/2008JAS2696.1.

Pawson, S., R. S. Stolarski, A. R. Douglass, P. A. Newman, J. E. Nielsen, S. M. Frith, and M. L. Gupta (2008), Goddard Earth Observing System chemistry-climate model simulations of stratospheric ozone-temperature coupling between 1950 and 2005, J. Geophys. Res., 113, D12103, doi:10.1029/2007JD009511.

Rayner, N. A., D. E. Parker, E. B. Horton, C. K. Folland, L. V. Alexander D. P. Rowell, E. C. Kent, and A. Kaplan (2003), Global analyses of sea surface temperature, sea ice, and night marine air temperature since the late nineteenth century, J. Geophys. Res., 108(D14), 4407, doi:10.1029/2002JD002670.

Rienecker, M. M., et al., (2008), The GEOS-5 data assimilation system - Documentation of versions 5.0.1, 5.1.0, and 5.2.0, Tech. Rep. Ser on Global Model. and Data Assim., 27, NASA Goddard Space and
Flight Center, Greenbelt, MD. [Available at http://gmao.gsfc.nasa.gov/ pubs/docs/Rienecker369.pdf]

Scaife, A. A., N. Butchart, D. R. Jackson, and R. Swinbank (2003), Can changes in ENSO activity help to explain increasing stratospheric water vapor? Geophys. Res. Lett., 30 (17), 1880, doi:10.1029/ 2003 GL017591.

Scherllin-Pirscher, B., C. Deser, S.-P. Ho, C. Chou, W. Randel, and Y.-H. Kuo (2012), The vertical and spatial structure of ENSO in the upper troposphere and lower stratosphere from GPS radio occultation measurements, Geophys. Res. Lett., 39, L20801, doi:10.1029/ 2012GL053071.

Solomon, S., R. R. Garcia, F. S. Rowland, and D. J. Wuebbles (1986), On the depletion of Antarctic ozone, Nature, 321, 755-758, doi: $10.1038 / 321755 \mathrm{a} 0$.

Solomon, S., K. H. Rosenlof, R. W. Portmann, J. S. Daniel, S. M. Davis, T. J. Sanford, and G.-K. Plattner (2010), Contributions of stratospheric water vapor to decadal changes in the rate of global warming, Science, 327, 1219-1223, doi:10.1126/science.1182488.

SPARC-CCMVal, (2010), SPARC report on the evaluation of chemistryclimate models, edited by V. Eyring, T. G. Shepherd, D. W. Waugh, SPARC Rep. 5, WCRP-132, WMO/TD-No. 1526, Stratospheric Processes and Their Role in Climate. [Available at http://www.sparc-climate.org/ publications/sparc-reports/sparc-report-no5/].

Trenberth, K. E., and D. P. Stepaniak (2001), Indices of El Niño evolution, J. Clim., 14, 1697-1701, doi:10.1175/1520-0442(2001)014h1697: LIOENOi2.0.CO;2.

Xie, F., J. P. Li, W. S. Tian, and J. Feng (2012), Signals of El Niño modoki in the tropical tropopause layer and stratosphere, Atmos. Chem. Phys. 12, 5259-5273, doi:10.5194/acp-12-5259-2012.

Yeh, S.-W., J.-S. Kug, B. Dewitte, M.-H. Kwon, B. P. Kirtman, and F.-F. Jin (2009), El Niño in a changing climate, Nature, 461, 511-514, doi:10.1038/nature08316.

Yu, J.-Y., and H.-Y. Kao (2007), Decadal changes of ENSO persistence barrier in SST and ocean heat content indices: 1958-2001, J. Geophys. Res., 112, D13106, doi:10.1029/2006JD007654

Zhou, X. L., M. A Geller, and M. Zhang (2004), Temperature fields in the tropical tropopause transition layer, J. Clim., 17(15), 2901-2908. 